\title{
RELEVANSI NILAI SELISIH LOANS BOOK VALUE DAN LOANS FAIR VALUE, BOOK VALUE PER SHARE, DAN EARNINGS PER SHARE TERHADAP HARGA SAHAM PERUSAHAAN PERBANKAN DI INDONESIA
}

\author{
Rizka Amalia Utami, Pipin Fitriasari \\ STIE Madani Balikpapan
}

\begin{abstract}
The goal of this research is to analyze the effect of the difference of loans book value and loans fair value, book value per share, and earnings per share to stock price on banks in Indonesia. The objects are 29 conventional banks which are listed in Indonesia Stock Exchange during 2015-2018 with 116 samples. The data used in this research is secondary data obtained from Indonesia Stock Exchange (www. idx.co.id). The hypothesis testing method are multiple linear regression analysis techniques using SPSS (Statistical Product and Service Solutions) application. After testing, the final results of the study showed that the difference between the loan book value and loans fair value with a significance value (sig. 0.760>0.05) had no effect on stock prices, earnings per share with a significance value (sig. 0.166> 0.05) no effect on stock prices, while for the variable book value per share with a significance value $(\mathbf{s i g .} \mathbf{0 , 0 0 0}<\mathbf{0 . 0 5})$ affect the stock price.
\end{abstract}

Keywords: Value Relevance, Difference of Loans Book Value and Loans Fair Value, Book Value Per Share, Earnings Per Share, Stock Price.

\section{PENDAHULUAN}

Saham dikenal sebagai instrumen keuangan yang paling sering diperjual belikan pada pasar modal. Tingginya harga saham mengindikasikan bahwa harga saham tersebut aktif diperdagangkan (Anoraga, 2006:100). Harga pasar menunjukkan seberapa baik manajemen menjalankan tugasnya atas nama pemegang saham. Menurut Widoatmojo (2012:30), semakin banyak orang yang ingin membeli saham, maka harga tersebut akan cenderung bergerak naik, dan sebaliknya. Bank adalah salah satu perusahaan yang turut serta dalam perdagangan saham di pasar modal. Pasar modal sebagai salah satu sarana bagi bank untuk memperoleh dana yang digunakan dalam kegiatan usahanya. Investor dapat mengetahui informasi mengenai kondisi perusahaan perbankan melalui laporan keuangan yang dipublikasikan di Bursa Efek Indonesia. Banyaknya jumlah perusahaan perbankan yang go 
public akan membuat investor dihadapkan pada banyak pilihan sulit dalam mengambil keputusan untuk berinvestasi di perusahaan perbankan.

Di sisi lain, untuk mendapatkan banyak investor, diperlukan laporan keuangan yang berkualitas dan relevan sesuai dengan kondisi sebenarnya. Relevansi nilai akuntansi dicirikan oleh kualitas informasi akuntansi (Lev, 1999). Informasi akuntansi dikatakan relevan apabila mampu mempengaruhi harga pasar saham (Reinita dan Deumes 2011). Loan atau kredit yang diberikan adalah salah satu komponen yang mencerminkan kondisi keuangan perbankan yang juga menjadi pertimbangan bagi investor. Pengukuran loan sebelumnya menggunakan metode historical cost. Namun sejak dilakukan adopsi penuh IFRS (International Financial Reporting Standards) 1 januari 2012 pada perusahaanperusahaan go public yang terdaftar di Bursa Efek Indonesia, penggunaan historical cost yang dalam konsep ini pos-pos laporan keuangan diukur sebesar cost (biaya) pada waktu terjadinya transaksi berubah menjadi konsep fair value. Adopsi penuh IFRS menimbulkan selisih antara nilai loan yang dicatat berdasarkan nilai buku (loans book value) dan loan yang dicatat berdasarkan nilai wajar (loans fair value). Berdasarkan latar belakang tersebut penulis tertarik untuk meneliti kembali hubungan antara selisih loans book value dan loans fair value, book value per share, dan earnings per share dengan harga saham. Berikut rumusan masalah dalam penelitian ini: (a) Apakah selisih antara Loans Book Value dan Loans Fair Value berpengaruh terhadap harga saham perbankan yang terdaftar di Bursa Efek Indonesia (BEI)? (b) Apakah Book Value Per Share (BVPS) berpengaruh terhadap harga saham perbankan yang terdaftar di Bursa Efek Indonesia (BEI)? (c) Apakah Earnings Per Share (EPS) berpengaruh terhadap harga saham perbankan yang terdaftar di Bursa Efek Indonesia (BEI)?

\section{KERANGKA TEORI}

\section{Harga Saham}

Saham adalah surat berharga sebagai bukti penyertaan atau pemilikan individu maupun institusi dalam suatu perusahaan (Anoraga, 2006:58). Saham sebagai tanda penyertaan atau pemilikan seseorang atau badan dalam suatu perusahaan atau perseroan terbatas (Darmadji, 2006:5).

Sedangkan harga saham merupakan nilai saham di pasar atau yang biasa disebut dengan harga pasar yang berfluktuasi dari waktu ke waktu tergantung dari prospek perusahaan di masa yang akan datang. Market price atau harga pasar merupakan harga pasar 
riil, dan merupakan harga yang paling mudah ditentukan Karena merupakan harga dari suatu saham pada pasar yang sedang berlangsung atau jika pasar sudah ditutup, maka harga pasar adalah harga penutupannya atau closing price (Anoraga, 2006:59).

\section{Jenis Nilai Saham}

Sunariyah (2006) menyatakan bahwa nilai sertifikat saham dapat dibagi menjadi empat, yaitu :

1) Nilai nominal (par value), yaitu harga saham pertama yang tercantum pada sertifikat badan usaha.

2) Nilai buku (book value) menggambarkan perbandingan total modal (ekuitas) terhadap jumlah saham.

3) Nilai dasar (base value) nilai ini merupakan harga perdana suatu saham setelah dilakukan penyesuaian karena corporate action (aksi emiten).

4) Nilai pasar (market value), harga suatu saham pada pasar yang sedang berlangsung di bursa efek. Saat bursa efek telah tutup maka harga pasar adalah harga penutupannya (clossing price).

\section{Faktor-Faktor Yang Mem-pengaruhi Harga Saham}

a. Faktor yang bersifat fundamental

Faktor fundamental sendiri merupakan faktor yang memberikan informasi tentang kinerja perusahaan dan faktor-faktor lain yang mempengaruhinya.

b. Faktor yang bersifat teknis

Faktor teknis menyajikan informasi yang menggambarkan pasaran suatu efek, baik secara indvidu maupun secara kelompok.

c. Faktor sosial politik

Faktor sosial politik adalah faktor yang timbul dari kegiatan sosial politik dalam suatu Negara.

\section{Metode Analisa Saham}

Terdapat dua pendekatan atau analisis yang harus dilakukan investor dalam menganalisis suatu harga efek khususnya saham, yaitu: pendekatan fundamental (mendasarkan pada informasi-informasi yang diterbitkan oleh emiten yang dikaitkan dengan faktor-faktor fundamental seperti perekonomian makro, kondisi sektor industri, dan kinerja emiten) dan analisis teknikal yang analisisnya mendasarkan pada data harga saham di masa lalu sebagai upaya untuk memperkirakan harga saham di masa mendatang serta cenderung mengabaikan 
risiko dan pertumbuhan laba dalam menentukan barometer dari penawaran dan permintaan terhadap saham (Halim, 2005: 5).

\section{Relevansi Nilai}

Relevansi adalah suatu kapasitas informasi yang mempengaruhi keputusan pemakai informasi untuk memprediksi kejadian di masa lalu, kini dan masa yang mendatang atau mengkonfirmasi dan mengkoreksi pengharapan sebelumnya. Sebuah laporan keuangan bisa dikatakan relevan apabila data yang diolah atau informasi yang disajikan hanya yang berkaitan dengan transaksi yang bersangkutan (Muqodim, 2005:77).

\section{Loan (Pinjaman)}

Secara sederhana, pinjaman dapat diartikan sebagai barang atau jasa yang menjadi kewajiban pihak yang satu untuk dibayarkan kepada pihak lain sesuai dengan perjanjian tertulis ataupun lisan, yang dinyatakan atau diimplikasikan serta wajib dibayarkan kembali dalam jangka waktu tertentu (Ardiyos, 2004). Menurut PSAK 55 (2016) pinjaman yang diberikan dan piutang adalah aset keuangan nonderivatif dengan pembayaran tetap atau telah ditentukan dan tidak mempunyai kuotasi di pasar aktif.

\section{Hipotesis}

1. Pengaruh Selisih Loans Book Value dan Loans Fair Value Terhadap Harga Saham.

Hasil penelitian yang dilakukan oleh Pertiwi dan Suhardianto (2016) menjelaskan bahwa terdapat pengaruh yang signifikan dari selisih loans book value dan loans fair value terhadap harga saham. Hal ini berarti bahwa loans book value dan loans fair value memiliki relevansi nilai (value relevance) dalam menjelaskan harga saham ketika loans book value dan loans fair value-nya berbeda. Hasil penelitian tersebut sesuai dengan penelitian Drago, et al. (2013). Berdasarkan hal tersebut maka dirumuskan hipotesis sebagai berikut :

$\mathrm{H}_{1}$ : Selisih loans book value dan loans fair value berpengaruh terhadap harga saham.

2. Pengaruh Book Value Per Share (BVPS) Terhadap Harga saham

Nilai Buku Ekuitas memberikan pengaruh yang positif terhadap harga saham. Hubungan yang positif antara nilai buku ekuitas dengan harga saham dapat diartikan bahwa semakin tinggi nilai buku ekuitas akan menimbulkan reaksi yang positif dari pasar. Secara konseptual bahwa semakin besar nilai buku ekuitas akan semakin tinggi harga saham. Pernyataan tersebut sesuai dengan hasil penelitian yang dilakukan oleh Gunistiyo dan Sumarno (2009) bahwa BVPS berpengaruh positif dan 
signifikan terhadap return saham. Berdasarkan uraian tersebut dapat dirumuskan hipotesis sebagai berikut:

$\mathrm{H}_{2}$ : Book value per share berpengaruh terhadap harga saham.

3. Pengaruh Earnings Per Share (EPS) Terhadap Harga Saham

Penelitian yang dilakukan oleh Marcellyna dan Hartini (2013) mendapatkan hasil bahwa Earnings Per Share (EPS) memiliki pengaruh terhadap harga saham. EPS menunjukkan kemampuan perusahaan dalam menghasilkan keuntungan bersih dalam setiap lembar sahamnya. Semakin tinggi nilai EPS berarti semakin baik karena akan meningkatkan harga saham dan ini akan menguntungkan perusahaan. Implikasinya adalah pengetahuan investor tentang EPS sangat penting untuk melakukan penilaian berapa perkiraan potensi pendapatan yang dapat diterima jika membeli suatu saham. EPS merupakan jumlah laba atau keuntungan yang diperoleh dalam satu periode untuk tiap lembar saham. Dengan demikian jika EPS meningkat maka pasar akan merespon positif dengan diikuti kenaikan harga saham. Berdasarkan uraian tersebut dapat dirumuskan hipotesis sebagai berikut:

$\mathrm{H}_{3}$ : Earnings per share berpengaruh terhadap harga saham.

\section{METODE PENELITIAN}

\section{Jenis Penelitian}

Jenis Penelitian ini menggunakan penelitian kuantitatif dengan metode asosiatif. Metode penelitian asosiatif ini merupakan penelitian yang dilakukan untuk menganalisis hubungan atau pengaruh antara dua variabel atau lebih. Penelitian ini bertujuan untuk menganalisis antara variabel selisih loans book value dan loans fair value, book value per share, dan earnings per share terhadap harga saham pada perusahaan perbankan yang terdaftar di Bursa Efek Indonesia.

\section{Data Penelitian}

Berdasarkan sumbernya, data yang digunakan dalam penelitian ini seluruhnya adalah data sekunder eksternal, yaitu data yang tidak langsung didapat dari perusahaan, tapi diperoleh dalam bentuk data yang telah dikumpulkan, diolah dan dipublikasikan oleh pihak lain yaitu Bursa Efek Indonesia berupa data melalui internet (www.idx.co.id) dalam hal ini data keuangan dari tahun 2015-2018. Jumlah populasi perbankan yang terdaftar di Bursa Efek Indonesia sendiri yaitu sebanyak 45 perbankan. Sedangkan untuk sampelnya, penulis 
memilih bank yang telah menerbitkan laporan keuangan audited dari tahun 2015-2018 dan benar-benar menyajikan loans fair value dan loans book value dalam catatan atas laporan keuangannya.

\section{Teknik Pengumpulan Data}

Untuk mendapatkan data yang relevan, penelitian ini menggunakan teknik dokumentasi dalam pengumpulan data secara tahunan yaitu dari periode 2015 sampai dengan 2018 melalui data keuangan yang telah dipublikasikan oleh perusahaan-perusahaan perbankan melalui situs Bursa Efek Indonesia (www.idx.co.id).

\section{Populasi dan Sampel}

Populasi dari penelitian ini adalah perusahaan perbankan yang terdaftar di Bursa Efek Indonesia (BEI) dari tahun 2015-2018. Penentuan sampel dalam penelitian ini menggunakan teknik purposive sampling yang bertujuan untuk mendapatkan sampel yang representative yakni sesuai dengan kriteria yang ditentukan. Kriteria pemilihan sampel yang digunakan yakni sebagai berikut :

1. Bank-bank tersebut terdaftar di Bursa Efek Indonesia dan tidak sedang dalam proses delisting untuk periode 2015-2018.

2. Bank-bank tersebut menerbitkan laporan keuangan tahunan untuk periode 20152018 secara berturut-turut.

3. Bank-bank tersebut me-ngungkapkan nilai pinjaman baik nilai tercatat maupun nilai wajar dalam catatan atas laporan keuangannya untuk periode 2015-2018 secara berturut-turut.

Berikut merupakan tabel untuk melihat jumlah sampel akhir yang memenuhi kriteria di atas.

Tabel 3.1

Prosedur Seleksi Sampel

\begin{tabular}{|c|l|l|}
\hline No. & \multicolumn{1}{|c|}{ Klasifikasi } & Perusahaan \\
\hline 1 & $\begin{array}{l}\text { Bank yang terdaftar di Bursa Efek Indonesia dan tidak dalam proses delisting } \\
\text { periode 2015-2018. }\end{array}$ & 45 \\
\hline 2 & $\begin{array}{l}\text { Bank yang tidak menerbitkan laporan keuangan tahunan untuk periode 2015- } \\
\text { 2018 secara berturut-turut }\end{array}$ & $(16)$ \\
\hline 3 & $\begin{array}{l}\text { Bank yang tidak mengungkapkan nilai pinjaman baik nilai tercatat maupun nilai } \\
\text { wajar dalam catatan atas laporan keuangan 2015-2018 secara berturut-turut. }\end{array}$ & $(0)$ \\
\hline \multicolumn{2}{|}{\begin{tabular}{|c|c|} 
Jumlah sampel perusahaan \\
Jumlah tahun pengamatan
\end{tabular}} \\
\hline & Jumlah keseluruhan sampel 29 x 4 \\
\hline
\end{tabular}


Populasi penelitian adalah perusahaan perbankan yang terdaftar di Bursa Efek Indonesia (BEI) dari tahun 2015-2018. Jumlah sampel perusahaan dikalikan dengan jumlah tahun pengamatan yaitu 29 x 4 didapatkan 116 sampel yang memenuhi kriteria.

\section{Variabel Dependen (Y)}

Variabel dependen dalam penelitian ini adalah harga saham perbankan konvensional yang terdaftar di Bursa Efek Indonesia. Harga saham merupakan nilai saham di pasar atau yang biasa disebut dengan harga pasar yang berfluktuasi dari waktu ke waktu tergantung dari prospek perusahaan di masa yang akan datang (Anoraga, 2006:59). Sesuai dengan penelitian sebelumnya yang dilakukan oleh Pertiwi dan Suhardianto (2016) harga saham yang digunakan adalah rata-rata harga saham penutupan tiga bulan setelah akhir tahun buku.

\section{Variabel Independen $(\mathrm{X})$}

\section{Selisih Loans Book Value dan Loans Fair Value}

Sejak adosi penuh IFRS, pengguna laporan keuangan memiliki dua informasi nilai kredit, yaitu nilai buku (loans book value) dan nilai wajar (loans fair value). Selisih nilai wajar dan nilai buku kredit dapat menjadi indikasi kenaikan atau penurunan laba dan aliran arus kas masuk yang diharapkan di masa mendatang. Selain itu selisih antara loans book value dan loans fair value mampu mendeteksi kemampuan manajemen bank dalam menjaga kualitas loan (Pertiwi dan Suhardianto, 2016). Secara matematis selisih loans book value dan loans fair value dapat diformulasikan sebagai berikut :

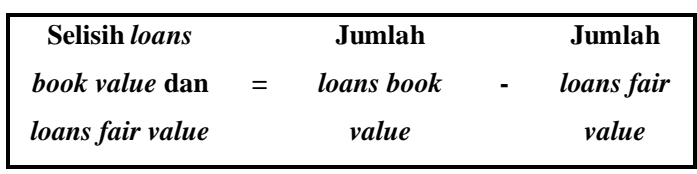

\section{Book Value Per Share (BVPS)}

Book value per share (BVPS) merupakan rasio yang digunakan untuk menunjukkan besarnya nilai riil suatu saham. Book value per share (BVPS) juga merupakan rasio yang membandingkan antara jumlah ekuitas dengan jumlah saham yang beredar. Kinerja perusahaan dapat dicerminkan melalui nilai book value per share (BVPS) ini. Jika book value per share (BVPS) meningkat, maka kinerja perusahaan dapat dikatakan meningkat juga yang nantinya akan menyebabkan peningkatan harga 
saham karena semakin banyak investor yang tertarik untuk berinvestasi di perusahaan dengan nilai book value per share yang meningkat tersebut (Achiriyantiningsih, 2013). Secara matematis book value per share (BVPS) dapat diformulasikan sebagai berikut:

BVPS $=\frac{\text { Jumlah ekuitas }}{\text { Jumlah saham beredar }}$

\section{Earnings Per Share (EPS)}

Earning per share (EPS) menunjukkan kemampuan suatu perusahaan dalam menghasilkan laba untuk setiap saham yang dimiliki oleh investor (Hatta dan Dwiyanto, 2012). Secara matematis earning per share (EPS) dapat diformulasikan sebagai berikut:

EPS $=\frac{\text { Laba setelah pajak }}{\text { Jumlah saham beredar }}$

\section{HASIL PENELITIAN DAN PEMBAHASAN}

\section{Analisis Statistik Deskriptif}

Analisis statistik deskriptif adalah bagian ilmu statistik yang hanya mengolah dan menyajikan data tanpa pengambilan keputusan. Dengan kata lain hanya melihat gambaran secara umum dan data yang didapatkan. Deskripsi dari variabel-variabel penelitian itu sendiri dapat ditunjukkan oleh tabel 4.2 sebagai berikut:

Tabel 4.2

\begin{tabular}{|l|c|r|r|c|c|}
\hline & $\mathrm{N}$ & Min & \multicolumn{1}{c|}{ Max } & Mean & $\begin{array}{c}\text { Std. } \\
\text { Deviation }\end{array}$ \\
\hline Price & 116 & 24,00 & 77.30 & $3.393,78$ & $8.622,31$ \\
DIF_LBV & & - & 60.60 & & \\
LFV & 116 & 5.437 .44 & 6.600. & 1.469 .965$. & 8.493 .496$. \\
& & 2. & 000.0 & 353.448 & 936.523 \\
BVPS & 116 & 000.000 & 00 & & \\
EPS & 10,82 & $\begin{array}{r}6.573, \\
08\end{array}$ & $1.289,13$ & $1.648,29$ \\
$\begin{array}{l}\text { Valid N } \\
\text { (listwise) }\end{array}$ & 116 & $-32,23$ & $\begin{aligned} 1.065, \\
52\end{aligned}$ & 148,39 & 259,07 \\
\hline
\end{tabular}

Tabel 4.2 di atas menjelaskan bahwa jumlah data yang digunakan dalam penelitian ini adalah 116 data. Untuk variabel harga saham (Y) memiliki nilai minimum sebesar 24,00 yaitu nilai harga saham perusahaan Bank Pembangunan Daerah Banten Tbk dan nilai maksimum sebesar 77.300,00 yaitu nilai harga saham perusahaan Bank Central Asia Tbk. 
Nilai Rata-rata yang didapat dari 116 observasi adalah sebesar 3.393,78 dengan standar deviasi 8.622,31. Variabel selisih loans book value dan loans fair value $\left(\mathrm{X}_{1}\right)$ memiliki nilai minimum sebesar -5.437.442.000.000 yaitu nilai selisih loans book value dan loans fair value perusahaan Bank Maybank Indonesia Tbk dan nilai maksimum sebesar 60.606.600.000.000 yaitu nilai selisih loans book value dan loans fair value perusahaan Bank Rakyat Indonesia Tbk. Nilai Rata-rata yang didapat dari 116 observasi adalah sebesar 1.469.965.353.448 dengan standar deviasi 8.493.496.936.523.

Variabel book value per share $\left(\mathrm{X}_{2}\right)$ memiliki nilai minimum sebesar 10,82 yaitu nilai selisih book value per share perusahaan Bank Pembangunan Daerah Banten Tbk dan nilai maksimum sebesar 6.573,08 yaitu nilai book value per share perusahaan Bank Mandiri Tbk. Nilai Rata-rata yang didapat dari 116 observasi adalah sebesar 1.289,13 dengan standar deviasi 1.648,29. Variabel earnings per share $\left(\mathrm{X}_{3}\right)$ memiliki nilai minimum sebesar -32,23 yaitu nilai selisih earnings per share perusahaan Bank MNC International Tbk dan nilai maksimum sebesar 1.065,52 yaitu nilai earnings per share perusahaan Bank Rakyat Indonesia Tbk. Nilai Rata-rata yang didapat dari 116 observasi adalah sebesar 148,39 dengan standar deviasi 259,07.

\section{Hasil Analisis Regresi Linear Berganda}

Tabel 4.7

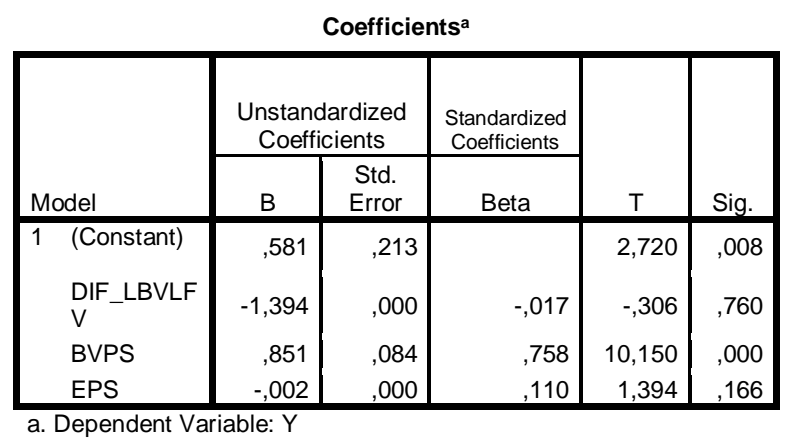

Berdasarkan tabel 4.7 diperoleh hasil persamaan regresi linier berganda dengan persamaan sebagai berikut:

$$
Y=0,581-1,394 X_{1}+0,851 X_{2}-0,002 X_{3}
$$

Berdasarkan persamaan tersebut, selanjutnya dapat dijelaskan sebagai berikut: 
1. 0,581 adalah nilai konstanta yang menunjukkan variabel $\mathrm{Y}$ (harga saham) akan bernilai 0,581 jika selisih loans book value dan loans fair value, book value per share, dan earnings per share bernilai 0 atau konstan.

2. -1,394 adalah nilai koefisien regresi dari selisih loans book value dan loans fair value hal ini menunjukkan bahwa setiap penambahan $1 \%$ selisih loans book value dan loans fair value (dengan asumsi bahwa nilai koefisien variabel lain konstan atau tidak berubah), maka akan

mengakibatkan penurunan harga saham perusahaan sebesar 1,394 atau $139 \%$ koefisien bernilai negatif antara selisih loans book value dan loans fair value dengan harga saham perusahaan

3. 0,851 adalah nilai koefisien regresi dari book value per share hal ini menunjukkan bahwa setiap penambahan $1 \%$ book value per share (dengan asumsi bahwa nilai koefisien variabel lain konstan atau tidak berubah), maka akan mengakibatkan kenaikan harga saham perusahaan sebesar 0,851 atau $85 \%$ koefisien bernilai positif antara book value per share dengan harga saham perusahaan.

4. -0,002 adalah nilai koefisien regresi dari earnings per share hal ini menunjukkan bahwa setiap penambahan $1 \%$ earnings per share (dengan asumsi bahwa nilai koefisien variabel lain konstan atau tidak berubah), maka akan mengakibatkan penurunan harga saham perusahaan sebesar 0,002 atau 0,2\% koefisien bernilai negatif antara earnings per share dengan harga saham perusahaan.

\section{Hasil Analisis Sensitivitas}

Analisis sensitivitas pada penelitian dilakukan pada sampel perusahaan yang antara loans book value dan loans fair value menunjukkan perbedaan nilai atau memiliki selisih. Dari keseluruhan sampel yang dipilih, terdapat 18 sampel yang menunjukkan selisih tidak sama dengan nol. Hasil analisis regresi linier berganda pada sampel ini akan dijelaskan pada tabel 4.8 berikut.

Tabel 4.8

\begin{tabular}{|c|c|c|c|c|c|}
\hline & \multicolumn{3}{|c|}{ Coefficients $^{\mathrm{a}}$} & \multirow[b]{3}{*}{$T$} & \multirow[b]{3}{*}{ Sig. } \\
\hline \multirow[b]{2}{*}{ Model } & \multicolumn{2}{|c|}{$\begin{array}{l}\text { Unstandardized } \\
\text { Coefficients }\end{array}$} & \multirow{2}{*}{\begin{tabular}{|c|}
$\begin{array}{c}\text { Standardized } \\
\text { Coefficients }\end{array}$ \\
Beta \\
\end{tabular}} & & \\
\hline & B & $\begin{array}{l}\text { Std. } \\
\text { Error }\end{array}$ & & & \\
\hline $\begin{array}{ll}1 & \text { (Constant) }\end{array}$ & , 172 & ,369 & &, 467 & ,642 \\
\hline DIF_LBVLFV & $-1,311$ & ,000 &,- 022 &,- 281 & ,780 \\
\hline BVPS & ,983 & 135 & ,769 & 7,265 &, 000 \\
\hline EPS &,- 001 & ,000 & ,089 & ,803 & ,425 \\
\hline
\end{tabular}


Jurnal Akuntansi Manajemen Madani

Vol. 6, No. 1, Maret 2020

Berdasarkan tabel 4.8 diperoleh hasil persamaan regresi linier berganda dengan persamaan sebagai berikut :

$Y=0,172-1,311 X_{1}+0,983 X_{2}-0,001 X_{3}$

Berdasarkan persamaan tersebut, selanjutnya dapat dijelaskan sebagai berikut:

1. 0,172 adalah nilai konstanta yang menunjukkan variabel $\mathrm{Y}$ (harga saham) akan bernilai 0,172 jika selisih loans book value dan loans fair value, book value per share, dan earnings per share bernilai 0 atau konstan.

2. -1,311 adalah nilai koefisien regresi dari selisih loans book value dan loans fair value hal ini menunjukkan bahwa setiap penambahan $1 \%$ selisih loans book value dan loans fair value (dengan asumsi bahwa nilai koefisien variabel lain konstan atau tidak berubah), maka akan mengakibatkan penurunan harga saham perusahaan sebesar 1,311 atau $131 \%$ koefisien bernilai negatif antara selisih loans book value dan loans fair value dengan harga saham perusahaan. 0,983 adalah nilai koefisien regresi dari book value per share hal ini menunjukkan bahwa setiap penambahan $1 \%$ book value per share (dengan asumsi bahwa nilai koefisien variabel lain konstan atau tidak berubah), maka akan mengakibatkan kenaikan harga saham perusahaan sebesar 0,983 atau 98\% koefisien bernilai positif antara book value per share dengan harga saham perusahaan.

3. $-0,001$ adalah nilai koefisien regresi dari earnings per share hal ini menunjukkan bahwa setiap penambahan 1\% earnings per share (dengan asumsi bahwa nilai koefisien variabel lain konstan atau tidak berubah), maka akan mengakibatkan penurunan harga saham perusahaan sebesar 0,001 atau $0,1 \%$ koefisien bernilai negatif antara earnings per share dengan harga saham perusahaan.

\section{Pengujian Hipotesis}

\section{Uji Koefisien Korelasi (R)}

Koefisien korelasi menujukkan korelasi antara dua atau lebih variabel independen terhadap variabel dependen. Berdasarkan hasil perhitungan tabel 4.9 pada model regresi pertama diperoleh nilai R sebesar 0,836 atau 83,6\%. Nilai koefisien korelasi ini berada dalam rentang 0,80 - 1,000 yang menunjukkan adanya hubungan yang sangat kuat antara selisih loans book value dan loans fair value, book value per share, dan earnings per share terhadap harga saham.

\section{Uji Koefisien Determinasi (Adjusted R square)}


Koefisien determinasi digunakan untuk menunjukkan pengaruh variabel independen terhadap variabel dependen. Nilainya dari uji koefisien determinasi itu sendiri berada pada rentang 0-1. Semakin mendekati angka 1 maka semakin kuat pula variabel independen mempengaruhi variabel dependen. Pada tabel 4.9 dapat dilihat nilai adjusted $R$ square sebesar 0,691 atau 69,1\%. Nilai ini menunjukkan bahwa variabel selisih loans book value dan loans fair value, book value per share, dan earnings per share memberikan pengaruh terhadap harga saham sebesar 69,1\% sedangkan 30,9\% sisanya dipengaruhi oleh variabel lain atau variabel yang belum diteliti dalam penelitian ini.

\section{Uji F (F Test)}

Uji ini di maksudkan untuk melihat kemampuan menyeluruh dari variabel bebas $\left(\mathrm{X}_{1}\right.$, $\mathrm{X}_{2}, \mathrm{X}_{3}$ ) dapat atau mampu menjelaskan tingkah laku atau keberagaman variabel terikat (Y). Berdasarkan hasil uji f dapat disimpukan bahwa dari hasil persamaan regresi yang

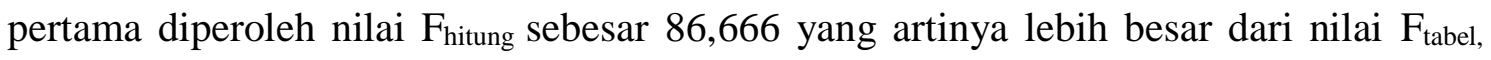
$86,666>2,69$. Dengan nilai signifikansi sebesar 0,000 yang artinya lebih kecil dari nilai alpha $0,05,0,000<0,05$ yang artinya $\mathrm{H}_{0}$ ditolak dan $\mathrm{H}_{\mathrm{a}}$ diterima. Sehingga dapat ditarik suatu keputusan bahwa secara simultan terdapat pengaruh antara variabel selisih loans book value dan loans fair value, book value per share, dan earnings per share terhadap harga saham.

\section{Uji Parsial (Uji t)}

Uji parsial (t) pada dasarnya menunjukkan seberapa jauh pengaruh satu variabel independen secara individual dalam menerangkan variasi variabel dependen (Ghozali, 2013:98). Berdasarkan hasil uji t dihasilkan signifikansi dari variabel selisih loans book value dan loans fair value adalah 0,760>0,05 sehingga dapat disimpulkan bahwa $\mathrm{H}_{0}$ diterima, signifikansi dari variabel book value per share adalah 0,000 0,05 sehingga dapat disimpulkan bahwa $\mathrm{H}_{0}$ ditolak, dan signifikansi dari variabel earnings per share $0,166>0,05$ sehingga dapat disimpulkan bahwa $\mathrm{H}_{0}$ diterima.

\section{Pengaruh Selisih Loans Book Value dan Loans fair Value terhadap Harga Saham}

Berdasarkan hasil pengujian hipotesis secara parsial (uji t) menunjukkan bahwa selisih loans book value dan loans fair value tidak berpengaruh terhadap harga saham. Hal ini dikarenakan dari $t_{\text {hitung }}<t_{\text {tabel }}$ atau $\mathbf{- 0 , 3 0 6}<\mathbf{1 , 9 8 1}$ dan nilai signifikansi $($ sig. $0,760>0,05)$ sehingga $\mathrm{H}_{\mathrm{o}}$ diterima artinya selisih loans book value dan loans fair value tidak berpengaruh terhadap harga saham. Sehingga didapatkan hasil bahwa hipotesis $\mathrm{H}_{1}$ yang menyatakan 
bahwa selisih loans book value dan loans fair value berpengaruh terhadap harga saham ditolak.

Hasil dalam penelitian ini menunjukkan bahwa secara parsial selisih loans book value dan loans fair value tidak berpengaruh terhadap harga saham. Hasil ini menunjukkan bahwa investor tidak selalu memperhatikan selisih nilai wajar dan nilai buku kredit untuk mengambil keputusan. Secara teoritis, selisih lebih nilai wajar dan nilai buku kredit seharusnya dapat mempengaruhi investor untuk memiliki saham perusahaan bersangkutan. Selisih lebih nilai wajar dan nilai buku loans dapat menjadi indikasi meningkatnya expected future cash flow entitas di masa mendatang. Dengan demikian kemampuan entitas untuk membagi dividen juga meningkat.

Salah satu kemungkinan penyebab selisih nilai wajar dan nilai buku loans yang tidak berpengaruh terhadap harga saham adalah dikarenakan investor kurang mempercayai keandalan nilai wajar kredit yang diberikan. Pengungkapan nilai wajar kredit mungkin saja tidak reliable. Berdasarkan hasil penelitian yang dilakukan Nissim (1996) bank cenderung mengungkapkan nilai wajar loans overstated. Menurut SFAC No. 8 karakteristik kualitatif yang fundamental dari informasi adalah relevan dan andal (relevance and reliability). Menurut Hendriksen dan Breda (1991) karakteristik kualitatif didefinisikan sebagai bagian dari informasi yang diperlukan untuk membuat informasi tersebut berguna. Sehingga jika informasi mengenai nilai wajar kredit tidak andal maka informasi tersebut bukanlah informasi yang berguna untuk mengambil keputusan. Penelitian ini sejalan dengan penelitian Prayscha dan Lestari (2017) dan penelitian Martuwinti (2017) yang menyatakan bahwa selisih loans book value dan loans fair value tidak berpengaruh terhadap harga saham

\section{Pengaruh Book Value Per Share terhadap Harga Saham}

Berdasarkan hasil pengujian hipotesis secara parsial (uji t) menunjukkan bahwa book value per share berpengaruh terhadap harga saham. Hal ini dikarenakan dari $t_{\text {hitung }}>\mathrm{t}_{\text {tabel }}$ atau 10,150 > 1,981 dan nilai signifikansi (sig. 0,000 < 0,05) sehingga $\mathrm{H}_{\mathrm{o}}$ ditolak artinya book value per share berpengaruh terhadap harga saham. Sehingga didapatkan hasil bahwa hipotesis $\mathrm{H}_{2}$ yang menyatakan bahwa book value per share berpengaruh terhadap harga saham diterima.

Hasil dalam penelitian ini menunjukkan bahwa secara parsial book value per share memiliki pengaruh signifikan terhadap harga saham. Hal ini menunjukkan bahwa investor mempertimbangkan rasio book value per share dalam pengambilan keputusan untuk 
berinvestasi. Informasi peningkatan book value per share diterima pasar sebagai sinyal baik yang akan memberikan masukan positif bagi para investor dalam pengambilan keputusan untuk membeli saham. Selain itu, Hasil penelitian ini juga menujukkan bahwa semakin tinggi book value per share maka akan meningkatkan harga saham perbankan. Hal ini terlihat dari meningkatnya jumlah modal perusahaan tiap tahunnya. Dengan meningkatnya jumlah modal perusahaan maka semakin besar peluang perusahaan untuk mengembangkan usahanya sehingga keuntungan yang diperoleh semakin besar. Dengan demikian maka harga saham juga akan mengalami peningkatan dan menjadi daya tarik bagi investor.

Hasil penelitian ini sesuai dengan penelitian Drago, et.al. (2013) yang menyatakan bahwa book value per share memiliki pengaruh signifikan terhadap harga saham. Sehingga nilai buku menjadi faktor penting dalam menentukan dan mengendalikan harga saham bank.

\section{Pengaruh Earnings Per Share terhadap Harga Saham}

Berdasarkan hasil pengujian hipotesis secara parsial (uji t) menunjukkan bahwa earnings per share tidak berpengaruh terhadap harga saham. Hal ini dikarenakan dari thitung $<t_{\text {tabel }}$ atau 1,394 < 1,981 dan nilai signifikansi (sig. 0,166 > 0,05) sehingga $\mathrm{H}_{\mathrm{o}}$ diterima artinya earnings per share tidak berpengaruh terhadap harga saham. Sehingga didapatkan hasil bahwa hipotesis $\mathrm{H}_{3}$ yang menyatakan bahwa earnings per share berpengaruh terhadap harga saham ditolak.

Hasil dalam penelitian ini menunjukkan bahwa secara parsial earnings per share tidak berpengaruh terhadap harga saham. Hal ini menunjukkan bahwa investor tidak selalu memperhatikan earnings per share dalam pengambilan keputusan investasi. terutama pada investor jangka panjang yang ingin menerima deviden atau alasan lain. Selain itu, kemungkinan penyebab earnings per share tidak berpengaruh terhadap harga saham adalah dikarenakan investor cenderung tidak menggunakan analisis fundamental dalam pengambilan keputusan melainkan investor menggunakan kelompok referensi, pengalaman dan mengikuti pergerakan bandar (spekulasi) dalam berinvestasi. Hal ini menunjukkan bahwa faktor psikologi dari investor mengambil peranan yang cukup penting dalam pengambilan keputusan investasi. Hasil penelitian ini sesuai dengan penelitian Raharjo (2013) dan Fitrias (2017) yang menyatakan bahwa earnings per share tidak berpengaruh terhadap harga saham.

\section{KESIMPULAN DAN SARAN Kesimpulan}


Berdasarkan hasil penelitian dan pembahasan yang telah dilakukan mengenai pengaruh antara variabel selisih loans book value dan loans fair value, book value per share, dan earnings per share terhadap harga saham pada perusahaan perbankan yang terdaftar di Bursa Efek Indonesia periode tahun 2015-2018, dapat ditarik kesimpulan sebagai berikut:

1. Hasil penelitian menunjukkan bahwa selisih loans book value dan loans fair value tidak berpengaruh terhadap harga saham. Hal ini dikarenakan investor kurang mempercayai keandalan nilai wajar kredit yang diberikan. Sehingga investor tidak selalu memperhatikan selisih nilai wajar dan nilai buku kredit dalam pengambilan keputusan

2. Hasil penelitian menunjukkan bahwa book value per share memiliki pengaruh terhadap harga saham. Hal ini dikarenakan investor mempertimbangkan rasio book value per share dalam pengambilan keputusan untuk berinvestasi.

3. Hasil penelitian menunjukkan bahwa earnings per share tidak berpengaruh terhadap harga saham. Hal ini dikarenakan investor cenderung tidak menggunakan analisis fundamental dalam pengambilan keputusan melainkan investor menggunakan kelompok referensi, pengalaman dan mengikuti pergerakan bandar (spekulasi) dalam berinvestasi.

\section{Saran}

1. Bagi akademik dalam melakukan penelitian selanjutnya, dapat menambah variabel bebas lain yang dapat mempengaruhi harga saham. Seperti variabel instrumen keuangan jenis available for sale, held to maturity securities, dikarenakan nilai wajarnya tersedia di pasar aktif. Sehingga lebih mencerminkan nilai wajar yang objektif. Serta memperluas objek penelitian serta memperpanjang periode penelitian untuk mendapatkan hasil yang lebih akurat.

2. Bagi investor diharapkan dapat mempertimbangkan bukti empiris terkait variabel yang digunakan

3. dalam penelitian dan yang berpengaruh terhadap harga saham dalam pengambilan keputusan.

\section{DAFTAR PUSTAKA}

Abdul, Halim. 2005. Analisis Investasi. Edisi kedua. Jakarta : Salemba Empat. Alfabeta. 
Achiriyantiningsih, Ana. 2013. Pengaruh Debt to Equity Ratio (DER), Price Earning Ratio (PER), Net Profit Margin (NPM) dan Book Value Per Share (BVPS) Terhadap Harga Saham Perusahaan Manufaktur Sub Sektor Barang Konsumsi yang Terdaftar di Bursa Efek Indonesia (BEI) periode 2008-2012. Jurnal Akuntansi dan Keuangan. Universitas Maritim Raja Ali Haji Tanjungpinang.

Agnes, Sawir. 2000. Analisis Kinerja Keuangan dan Perencanaan keuangan Perusahaan. PT Gramedia Pustaka Utama.

Anoraga, Pandji. 2006. Pengantar Pasar Modal. Jakarta: Rineka Cipta.

Ardiyos. 2004. Kamus Besar Akuntansi. Jakarta : Citra Harta Prima.

Barth, M., Landsman, W. dan Lang, M. 2008. International Accounting Standards and Accounting Quality. Journal of Accounting Research, 46(3), 467-498.

Darmadji, Tjiptono dan Hendy M. Fakhruddin. 2011. Pasar Modal Di Indonesia. Edisi 3. Jakarta: Salemba Empat

Dendawijaya, L. 2005. Manajemen Perbankan. Jakarta: Penerbit Ghalia Indonesia.

Drago, D., Mazzuca, M., and Colonel, R. T. 2013. Do Loans Fair Value Affect Market Value? Evidence From European Banks. Journal of Financial Regulation and Compliance, 21(2), 108-120.

Eduardus, Tandelilin. 2001. Analisis Investasi dan Manajemen Risiko. Edisi Pertama. Yogyakarta: BPFE.

Fabozzi, Frank. J. 1999. Manajemen Investasi. Jakarta: Salemba Empat.

Fahmi, Irham. 2015. Pengantar Manajemen Keuangan Teori dan Soal Jawab. Bandung : Alfabeta.

Fitrias, Deppy Ayu. 2017. Pengaruh Earning Per Share (Eps), Debt To Equity Ratio (Der), Dan Return On Equity (Roe) Terhadap Harga Saham Pada Perusahaan Food And Beverage Yang Terdaftar Di Bursa Efek Indonesia Tahun 2013-2016. SKRIPSI. Surakarta : Universitas Muhammadiyah Surakarta.

Francis, J., and Schipper, K. 1999. Have Financial Statements Lost Their Relevance?. Journal of Accounting Research, 37(1), 319-352.

Ghozali, Imam. 2011. Aplikasi Analisis Multivariate Dengan Program SPSS. Semarang: Badan Penerbit Universitas Diponegoro.

Imam. 2013. Aplikasi Analisis Multivariate Dengan Program SPSS. Edisi Ketujuh. Semarang: Badan Penerbit Universitas Diponegoro.

Glory Augusta E.M. Sianipar, 2013. Analisis Komparasi Kualitas Informasi Akuntansi Sebelum dan Sesudah Pengadopsian Penuh IFRS di Indonesia. Diponegoro Journal of Accounting Volume 2, Nomor3.,Tahun 2013.

Grace Nainggolan, Susan. 2008. Pengaruh Variabel Fundamental Terhadap harga saham perusahaan manufaktur yang terdaftar di BEI. Medan. Universitas Sumatera Utara. 
Gunistiyo dan Sumarno. 2007. Pengaruh Book Value Per Share Terhadap Return Saham LQ-45 Di Bursa Efek Indonesia. Laporan Penelitian. Tegal. Universitas Pancasakti.

Hatta, Atika Jauharia., \& Dwiyanto, Bambang Sugeng. 2012. The Company Fundamental Factors And Systematic Risk In Increasing Stock Price. Journal of Economics, Business, and Accountancy Ventura Vol. 15 No. 2, August 2012, pages 245-256.

IAI. 2017. Standar Akuntansi Keuangan - PSAK 55 (Revisi 2014) Instrumen Keuangan: Pengakuan dan Pengukuran. Jakarta: Ikatan Akuntan Indonesia.

Jogiyanto, H.M. 2010. Teori Portofolio dan Analisis Investasi. Edisi Ketujuh. BPFE. Yogyakarta.

Karunarathne, W. V. A. D, and R.M.D.A.P. Rajapakse. 2009. The value relevance of financial statements information: with special reference to the listed companies in Colombo Stock Exchange. Working paper, Huazhong Normal University, China.

Kuswanto, Randy. Dkk. 2016. Relevansi Nilai Informasi Akuntansi pada Perusahaan Manufaktur yang Terdaftar di Bursa Efek Indonesia pada Tahun 2013-2014. Jurnal Akuntansi dan Keuangan. Universitas Maritim Raja Ali Haji Tanjung Pinang.

Lev, B. and Zarowin, P. 1999. The Boundaries of Financial Reporting

and How to Extend Them. Journal of Accounting Research, 37, 353-385.

Marcellyna dan Hartini. 2013. Pengaruh Earning Per Share (EPS), terhadap Harga Saham LQ45 di Bursa Efek Indonesia. Palembang : Sekolah Tinggi Ilmu Ekonomi Multi Data Palembang.

Martuwinti. 2017. Pengaruh Earning Per Share, Book Value Per Share, Loans Fair Value, Loans Book Value, dan Arus Kas Operasi Terhadap Harga Saham pada Perusahaan Perbankan yang Terdaftar di Bursa Efek Indonesia Tahun 2014-2016. Jurnal Akuntansi dan Keuangan . Fakultas Ekonomi Universitas Maritim Raja Ali Haji Tanjung Pinang.

Mukhtaruddin. 2007. Pengaruh Return On Assets (ROA), Return On Equity (ROE), Return On Investment (ROI), Debt to Equity Ratio (DER), dan Book Value (BV) terhadap harga saham property di BEI. Jurnal penelitian dan pengembangan akuntansi.

Munandar, Aris. 2016. Analisis Pengaruh Variabel Makroekonomi Terhadap Stabilitas Perbankan Syariah dan Perbankan Konvensional di Indonesia. THESIS. Yogyakarta: Universitas Islam Negri Sunan Kalijaga.

Muqodim. 2005. Teori Akuntansi. Edisi 1. Yogyakarta : Ekonisia.

Nissim, D. 2003. Reliability of Banks's Fair Value Disclosure for Loans. Review of Quantitative Finance and Accounting, 20, 335-384.

Nurbayani. 2017. Pengaruh Earnings Management terhadap Earnings Quality dengan Adopsi IFRS sebagai Variabel Moderasi. Jurnal Ilmiah

Akuntansi Peradaban. Vol. III No. 1 Juli 2017. 
Pertiwi, D., dan Suhardianto, N. 2015. Relevansi Nilai Selisih Loans Book Value dan Loans Fair Value, Book Value Per Share, Earnings Per Share dan Ukuran Perusahaan. Jurnal Akuntansi dan Keuangan, Vol. 17, No. 2, November 2015, 82-90.

Prayscha dan Lestari. 2017. Pengaruh Selisih Nilai Wajar dan Nilai Buku Kredit yang Diberikan Terhadap Return Saham. Universitas Atma Jaya Yogyakarta.

Priyatno, Duwi. 2013. Analisis Korelasi, Regresi, dan Multivariate dengan SPSS Cetakan 1. Yogyakarta: Gava Media.

Pura, Rahman. 2013. Pendekatan akuntansi 1 (Pendekatan siklus Akuntansi). Jakarta: Erlangga.

Puspitaningtyas, Zarah. 2012. Relevansi Nilai Informasi Akuntansi dan Manfaatnya bagi Investor. Jurnal Ekonomi dan Keuangan. Vol,16. No.2:164-183.

Reinita, I. S. M. 2011. Value Relevance of $R \& D$ Reporting. Master Thesis. University of Maastricht Faculty of Economics and Business Administration.

Rinati, Ina. 2009. Pengaruh ROA, ROE, dan NPM terhadap Harga Saham pada Perusahaan yang Tercantum dalam LQ-45. Fakultas Ekonomi Jurusan Akuntansi. Universitas Gunadarma, Depok.

Sihombing, Gregorius. 2008. Kaya dan Pintar Jadi Trader dan Investor Saham. Yogyakarta : UPP STIM YKPN.

Sonbay, Y. Y. 2010. Perbandingan Biaya Historis dan Nilai Wajar. Kajian Akuntansi, 2(1), $1-8$.

Sugiyono. 2003. Metode Penelitian. Bandung: Alfabeta.

Suharyadi dan Purwanto. 2008. Statistika Untuk Ekonomi dan Keuangan Modern Edisi 2 Buku 1. Jakarta: Salemba Empat.

Sujarweni, V. Wiratna. 2014. Metode Penelitian: Lengkap, Praktis, dan Mudah Dipahami. Yogyakarta: Pustaka Baru Press.

Sujianto. 2009. Aplikasi Statistik dengan SPSS 16.0. Jakarta : PT. Prestasi Pustaka.

Suliyanto, 2014. Statistika Non Parametrik. Yogyakarta: Andi Yogyakarta.

Sunariyah. 2006. Pengantar Pengetahuan Pasar Modal. Yogyakarta : UPP STIM YKPN.

Suprihatin, S., dan Tresnaningsih, E. 2013. Pengaruh Konvergensi International Financial Reporting Standards terhadap Relevansi Nilai Informasi Akuntansi: Studi Empiris pada Perusahaan yang Terdaftar di BEI. Prosiding Simposium Nasional Akuntansi(SNA) XVI, Manado.

Suryatmi, Mutia, 2014. Analisis Perbedaan Relevansi Nilai Informasi Akuntansi Sebelum dan Sesudah Konvergensi Internasional Financial Reporting Standars (IFRS). SKRIPSI. Padang: Universitas Negeri Padang

Tryfino. 2009. Cara Cerdas Berinvestasi Saham. Edisi 1. Jakarta: Transmedia Pustaka. 
Widoatmodjo, Sawidji. 2012. Cara Sehat Investasi di Pasar Modal. Edisi

Revisi. Jakarta: PT. Jurnalindo Aksara Grafika.

2017. Saham Sektor Perbankan Sering Jadi Acuan, Ini Alasannya.

https://smart-money.co/ekonomi/saham-sektor-perbankan-sering-jadi-acuan-inialasannya. 21 Maret 2019. (16.03).

2018. Saham Perbankan Mampu Bertahan. https://investasi.kontan.co.id/news/sahamperbankan-mampu-bertahan. 26 Maret 2019. (17.18).

2019. Historical Data - Harga Saham Harian.

https://finance.yahoo.com/quote/BBCA.JK/history?p=BBCA.JK. 13 Mei 2019. (12.30).

2019. Laporan Keuangan dan Tahunan Perusahaan Tercatat.

https://www.idx.co.id/perusahaan-tercatat/laporan-keuangan-dan-tahunan/. 17 Mei 2019. (11.20) 
Jurnal Akuntansi Manajemen Madani

Vol. 6, No. 1, Maret 2020 